\title{
Regional Trade as a Factor of Territorial Food Market Development
}

\author{
Eva V. Shcherbenko and Vasiliy V. Kuimov* \\ Siberian Federal University \\ 79 Svobodny, Krasnoyarsk, 660041, Russia
}

Received 26.05.2017, received in revised form 27.11.2017, accepted 06.12.2017

\begin{abstract}
The article presents the analysis of the state of the food trade sphere in Russia. It gives an estimation of retail trade in food products of the Krasnoyarsk Territory and reveals the trends of the development of retail trade of the FMCG format in the regional market. Besides, the article estimates the structure of the cost of a minimum set of food products, studies the influence of the sanctions policy on the formation of the food retail market and shows the role of trade in the process of adaptation of food market entities to the conditions of sanctions. In the end, the article gives the data on the dynamics of the assortment and prices of retail trade enterprises on food products and shows the results of research of new technologies of interaction between manufacturers and retail chains, including technologies of "Private label". The article also generalizes the role of retail trade in shaping the competitive conditions of the food market.
\end{abstract}

Keywords: food retail, retail trade, assortment of food products, prices for food products, private label.

DOI: 10.17516/1997-1370-0193.

Research area: economics.

\section{Introduction}

The sphere of trade is one of the most important spheres of life support for the population, which is not only directly dependent on other markets, but also affects the development of other industries, as it acts as a link between the manufacturer and the consumer. By means of it, market coordination of the commodity supply and consumer demand is carried out. As a source of cash proceeds, trade forms the basis for the financial stability of the state.

The retail industry of food products in the Russian Federation has consistently demonstrated high growth rates. Thus, from 2004 to 2015, the sector's turnover increased almost by 5 times and in 2015 amounted to more than 13 trillion rubles. According to the operative report of the Federal State Statistics Service, in 2016, compared to 2015, the retail trade turnover decreased by $5.2 \%$ in comparable prices and amounted to 28.137 trillion rubles. In January 2017, the retail trade turnover was 8.9 billion rubles and decreased by $0.7 \%$ against the level of January 2016. Per capita in the country as a whole, the sector's turnover also shows strong growth, which should determine

C) Siberian Federal University. All rights reserved

* Corresponding author E-mail address: kuimov1945@mail.ru; sherbenko@mail.ru 
the increase in the consumption of products per person as the reason for the increase in sales of retailers. However, the decline in consumer activity is currently a key factor affecting the development of the food retail market in Russia. Higher growth rates of turnover per capita are recorded for the group of food products. At the same time, experts note that the number of customers in grocery stores in the physical volume decreased by about $10 \%$ on average. The number of purchases in the check is also decreasing, and shoppers are increasingly giving priority to inexpensive goods. Thus, the growth in retail trade turnover, both in its total volume and per capita, confirms the trend of price growth (Table 1-2).

The rise in prices causes a decline in purchasing power in all categories of goods, a change in the structure of consumption, a shift in demand towards essential goods, cheaper goods (Pokupatel'naia sposobnost'...) (Fig. 1).

In the structure of retail turnover for eight years (until 2013), the share of non-food products increased and prevailed (Table 3).

However, in the period from 2013 to 2016, the share of food purchases in the total retail turnover of the region grew by more than $3 \%$. In 2016 and at the beginning of 2017, this trend continued. Thus, in 2016 in the structure of retail trade turnover, the share of food products, including beverages, as well as of tobacco products, amounted to $45.4 \%$, the share of non-food products amounted to $54.6 \%$.

\section{Statement of the problem}

Trade in the Krasnoyarsk Territory provides the sphere of final consumption of goods by

Table 1. Retail trade turnover in Russia, million rubles

\begin{tabular}{|c|c|c|c|c|c|}
\hline \multirow{2}{*}{} & \multirow{2}{*}{ Total } & \multicolumn{2}{|c|}{ Including } & $\begin{array}{c}\text { Retail trade turnover } \\
\text { of trading } \\
\text { organizations }{ }^{\text {1) }}\end{array}$ & $\begin{array}{c}\text { Sale in retail } \\
\text { markets and fairs }\end{array}$ \\
\cline { 3 - 4 } & & Food products ${ }^{2}$ & Non-food products ${ }^{3)}$ & 1735155,3 & 617119,0 \\
\hline 2000 & 2352274,3 & 1093195,2 & 1259079,1 & 2294218,0 & 775796,0 \\
\hline 2001 & 3070014,0 & 1416832,3 & 1653181,7 & 2842887,9 & 922475,7 \\
\hline 2003 & 3765363,6 & 1753919,6 & 2011444,0 & 3454648,5 & 1074984,4 \\
\hline 2004 & 564249632,9 & 2091747,8 & 2437885,1 & 4381550,9 & 1260946,8 \\
\hline 2005 & 7041509,1 & 2580299,2 & 3062198,5 & 5545798,0 & 1495711,1 \\
\hline 2006 & 8711919,9 & 3947402,3 & 4764517,6 & 7000310,4 & 1711609,5 \\
\hline 2007 & 10868976,4 & 4891343,5 & 5977632,9 & 9218579,4 & 1650397,0 \\
\hline 2008 & 13944183,1 & 6495646,2 & 7448536,9 & 12113250,1 & 1830933,0 \\
\hline 2009 & 14599153,1 & 7097079,1 & 7502074,0 & 12655449,2 & 1943703,9 \\
\hline 2010 & 16512047,0 & 8002168,2 & 8509878,8 & 14457153,8 & 2054893,2 \\
\hline 2011 & 19104336,5 & 9104324,3 & 10000012,2 & 16898443,1 & 2205893,4 \\
\hline 2012 & 21394526,2 & 9961361,5 & 11433164,7 & 19126304,5 & 2268221,7 \\
\hline 2013 & 23685913,5 & 11143008,9 & 12542904,6 & 21453829,3 & 2232084,2 \\
\hline 2014 & 26356237,3 & 12380805,5 & 13975431,8 & 24057249,0 & 2298988,3 \\
\hline 2015 & 27538370,8 & 13419312,7 & 14119058,1 & 25369766,8 & 2168604,0 \\
\hline
\end{tabular}

1) including individual entrepreneurs engaged in activities outside the market;

2) since 2008. Food products, including beverages, and tobacco products;

3) since 2008. Non-food products with the exception of tobacco products. 
Table 2. Retail trade turnover per capita for the Russian Federation, rubles

\begin{tabular}{|c|c|c|c|}
\hline \multirow{2}{*}{} & \multirow{2}{*}{ Total } & \multicolumn{2}{|c|}{ Including } \\
\cline { 2 - 4 } & & Food products $^{1)}$ & Non-food products $^{2)}$ \\
\hline 2000 & 16162 & 7511 & 11406 \\
\hline 2001 & 21181 & 9775 & 13947 \\
\hline 2002 & 26109 & 12162 & 16984 \\
\hline 2003 & 31557 & 14573 & 21256 \\
\hline 2004 & 39166 & 17910 & 26643 \\
\hline 2005 & 49063 & 22420 & 33306 \\
\hline 2006 & 60901 & 27595 & 41859 \\
\hline 2007 & 76111 & 34252 & 52182 \\
\hline 2008 & 97688 & 45506 & 52540 \\
\hline 2009 & 102245 & 49705 & 59573 \\
\hline 2010 & 115591 & 56018 & 69949 \\
\hline 2011 & 133633 & 63684 & 79839 \\
\hline 2012 & 149401 & 69562 & 87403 \\
\hline 2013 & 165051 & 77648 & 95663 \\
\hline 2014 & 180410 & 84747 & 96438 \\
\hline 2015 & 188096 & 91658 & \\
\hline
\end{tabular}

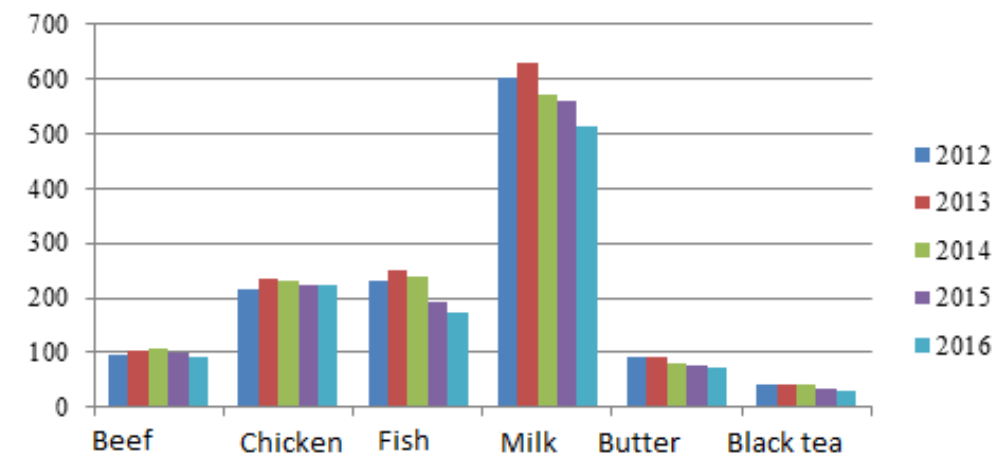

Fig. 1. Change in purchasing power of per capita money income of the population of the Russian Federation

Table 3. Structure of retail turnover of the Russian Federation by main commodity groups

\begin{tabular}{|l|c|c|c|c|c|c|c|c|c|c|c|c|}
\hline \multicolumn{1}{|c|}{ Years } & 2000 & 2006 & 2007 & 2008 & 2009 & 2010 & 2011 & 2012 & 2013 & 2014 & 2015 & 2016 \\
\hline Retail Turnover in Total & 100 & 100 & 100 & 100 & 100 & 100 & 100 & 100 & 100 & 100 & 100 & 100 \\
\hline $\begin{array}{l}\text { Food products } \\
\text { (including beverages and } \\
\text { tobacco products) }\end{array}$ & 53,8 & 44,3 & 41,4 & 44,2 & 47,5 & 45,4 & 43,7 & 41,9 & 41,8 & 43,1 & 45,2 & 45,4 \\
\hline Non-food products & 46,2 & 55,7 & 58,6 & 55,8 & 52,5 & 54,6 & 56,3 & 58,1 & 58,2 & 56,9 & 54,8 & 54,6 \\
\hline
\end{tabular}


nearly $2,875.8$ thousand people in total (this is a preliminary estimate of the number of permanent residents on January 1, 2017 according to Rosstat). The share of the employed in trade is $16.4 \%$ of the total number of the employed in the economy of the region.

The retail trade turnover in the Krasnoyarsk Territory for the period of 2016 amounted to 497.3 billion rubles, of which 225.7 billion rubles for food products, including beverages, and tobacco products. Compared to 2013, the retail trade turnover in value terms in 2016 increased by $1.07 \%$. However, we should note the decrease in the index of physical volume of turnover, which in 2014 was $101 \%$, while the last 2016 showed the volume indicator of $98.6 \%$.

Among the regions of the Siberian Federal District in terms of retail trade turnover per capita in 2012-2015, the Krasnoyarsk Territory ranks second, behind the Republic of Buryatia. In 2016, the Krasnoyarsk Territory was the leader in the Siberian Federal District in terms of retail trade turnover with 445,269.6 million rubles (Table 4) (Federal'naia sluzhba...).

The trend of increasing retail trade turnover per capita in the Krasnoyarsk Territory was maintained only until 2014. In 2015, its decrease down to 165.4 thousand rubles per capita is recorded, which is less than the corresponding indicator of 2014 by $4 \%$.

The increase in the money supply volume of sales explains the growth in average prices for all product groups. According to the data of the Territorial Body of the Federal State Statistics Service for the Krasnoyarsk Territory, the composite consumer price index for the period from the beginning of the year in September 2016 was $103.3 \%$ (100.4\% in 2015), including $102.2 \%$ for food products (99.7 \% in September 2015), $101.1 \%$ for nonfood products (100.8 \% in 2015), $103.5 \%$ for services (100.5\% in 2015).
The data on the level of prices for food products, which are given below for almost a decade, shows their significant growth, including the reporting period in 2016. According to statistics, the cost of a fixed set of food products in the Krasnoyarsk Territory in 2016 in relation to its value in 2015 grew by $2.9 \%$ and amounted to $4,152.71$ rubles per person. This set includes such groups of products as meat products, fish products, fats, dairy products, chicken eggs, sugar and confectionery products, bread, flour, cereals and pasta, fruit and vegetable products, including potatoes, etc. Increase in the cost of fixed set food products in 2015 in the Krasnoyarsk Territory was $9.4 \%$.

The largest share of the population's spending on food purchases falls on bread, flour, cereals and pasta, while it grew in 2016 compared with the previous period. The share of dairy products increased too. In 2016, however, the share of fruit and vegetable products and meat products in the total value of the conditional food package declined.

According to Krasnoyarskstat, the retail trade turnover of retail chains in the Krasnoyarsk Territory in 2016 amounted to 104 billion rubles. Compared to the figures of the previous year, the turnover increased by $6.3 \%$, including the volume of sales of food products, including beverages, and tobacco products - by $6.9 \%$, nonfood products - by $5.6 \%$.

According to the statistics body of the Krasnoyarsk Territory, the turnover of chain retailing is $20.9 \%$ of the retail trade turnover as a whole. Retail chains in 2016 accounted for $25.6 \%$ of the retail trade turnover in food products in the region, including beverages, and tobacco products $(23.7 \%$ in 2015$)$ and $17 \%$ of the retail trade in non-food products $(15.8 \%$ in 2015). Compared to the previous year, the retail trade turnover of retail chains increased by $6.3 \%$ in 2016 (Stolitsa 24). 


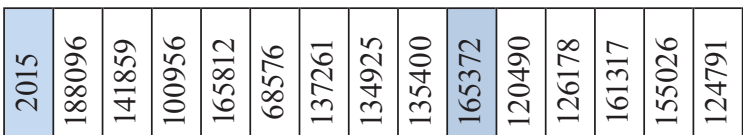

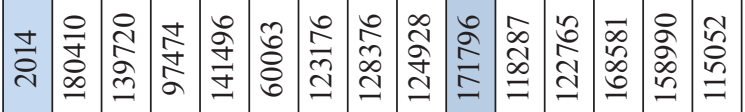

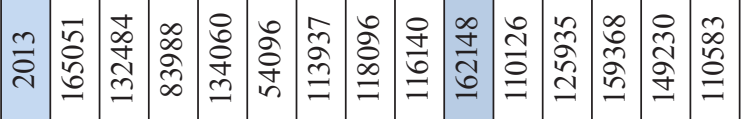

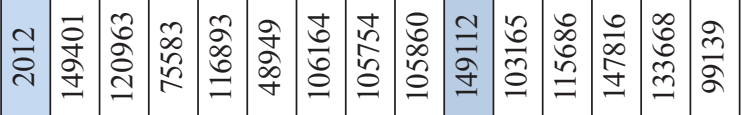

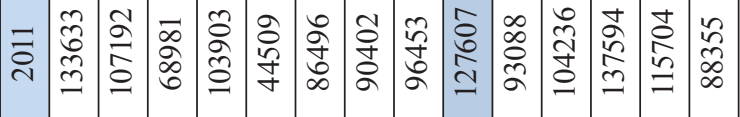

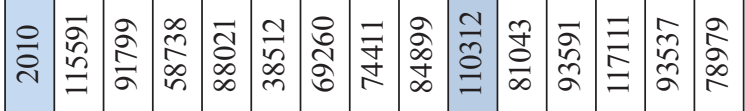

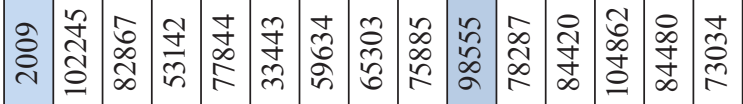

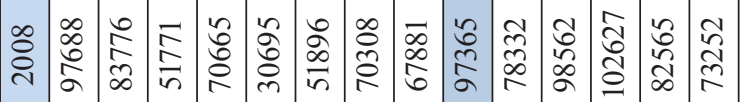

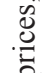

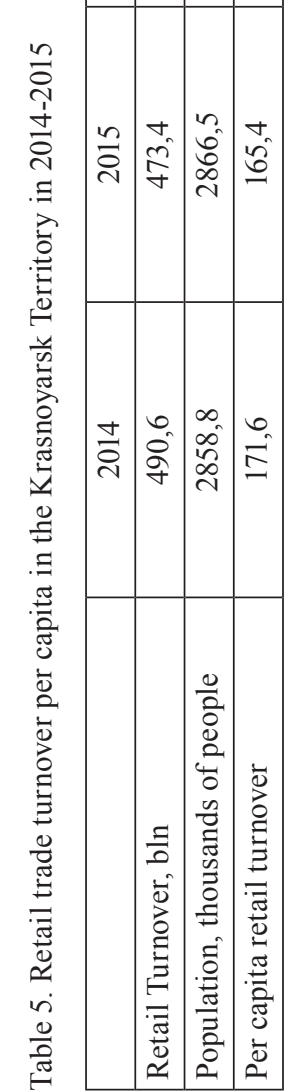




\begin{tabular}{|c|c|c|c|c|c|c|c|c|c|}
\hline & $\stackrel{\circ}{\stackrel{2}{\circ}}$ & $\mid \begin{array}{c}\stackrel{0}{0} \\
\stackrel{m}{m}\end{array}$ & $\begin{array}{l}\hat{\infty} \\
\dot{n}\end{array}$ & $\begin{array}{l}\text { ô } \\
\text { i } \\
\text { of }\end{array}$ & $\begin{array}{l}\infty \\
\stackrel{0}{0} \\
=\end{array}$ & $\begin{array}{l}2 \\
\infty \\
8 \\
\delta\end{array}$ & \begin{tabular}{l}
\multirow{2}{n}{} \\
ñ
\end{tabular} & 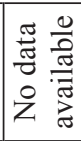 & 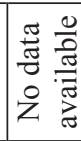 \\
\hline & $\stackrel{n}{\stackrel{\sim}{2}}$ & $\begin{array}{l}\vec{n} \\
\vec{\sim} \\
\tilde{n}\end{array}$ & $\begin{array}{l}\infty \\
\stackrel{\infty}{q} \\
q\end{array}$ & $\begin{array}{l}0 \\
\infty \\
\infty \\
o \\
+\end{array}$ & 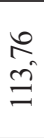 & $\begin{array}{l}m \\
\text { in }\end{array}$ & $\begin{array}{l}\hat{n} \\
\dot{n}\end{array}$ & $\begin{array}{|ll|}\frac{\pi}{\pi} & \frac{0}{d} \\
\frac{\pi}{\pi} & \frac{\pi}{\pi} \\
0 & \pi \\
z & \frac{\pi}{\pi}\end{array}$ & 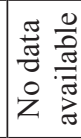 \\
\hline & $\stackrel{+}{\stackrel{i}{i}}$ & $\mid \begin{array}{c}\text { के } \\
\tilde{f} \\
\vec{v}\end{array}$ & $\begin{array}{l}\tilde{y} \\
\tilde{f}\end{array}$ & 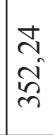 & $\begin{array}{l}\text { fo } \\
\text { fo } \\
\text { o }\end{array}$ & $\begin{array}{l}n \\
n \\
\tilde{n} \\
n\end{array}$ & $\frac{0}{2}$ & $\begin{array}{ll}\frac{\pi}{\pi} & \frac{0}{d} \\
\frac{\pi}{\pi} & \frac{\pi}{\pi} \\
0 & \frac{\pi}{\pi} \\
z & \frac{\pi}{\pi}\end{array}$ & 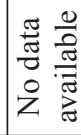 \\
\hline & $\stackrel{\sim}{\stackrel{\sim}{\sim}}$ & 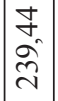 & $\overrightarrow{\sigma_{0}^{\circ}}$ & $\begin{array}{l}\hat{n} \\
\stackrel{+}{N}\end{array}$ & $\bar{\infty}$ & $\begin{array}{l}\stackrel{+}{2} \\
2 \\
\stackrel{2}{+}\end{array}$ & $\stackrel{尺}{\stackrel{\sim}{2}}$ & $\begin{array}{l}\text { D } \\
\text { ñ } \\
\text { n }\end{array}$ & $\begin{array}{l}\text { ते } \\
\stackrel{\sim}{\sim}\end{array}$ \\
\hline & $\overline{\vec{\nabla}}$ & $\begin{array}{l}n \\
\hat{n} \\
\approx \\
\approx\end{array}$ & $\begin{array}{l}\approx \\
\text { } \\
\dot{m}\end{array}$ & $\begin{array}{l}\text { D } \\
\text { if } \\
\text { an }\end{array}$ & $\begin{array}{l}\tilde{c} \\
\text { î. } \\
\infty\end{array}$ & $\begin{array}{l}\stackrel{\vec{m}}{\vec{F}} \\
\vec{F}\end{array}$ & $\begin{array}{l}\text { in } \\
\tilde{N}\end{array}$ & $\begin{array}{l}\text { oे } \\
\text { in }\end{array}$ & $\begin{array}{l}\bar{\sigma} \\
0 \\
0\end{array}$ \\
\hline & $\stackrel{\circ}{\stackrel{2}{\sim}}$ & $\begin{array}{l}\stackrel{2}{\partial} \\
\infty\end{array}$ & $\begin{array}{l}\infty \\
\infty \\
\approx\end{array}$ & $\begin{array}{l}\text { to } \\
\text { ñ } \\
\text { n. }\end{array}$ & 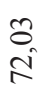 & $\begin{array}{l} \pm \\
0 \\
\infty \\
\infty\end{array}$ & $\frac{\hat{\sigma}}{\vec{i}}$ & 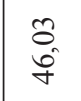 & $\begin{array}{l}\tilde{n} \\
\tilde{n}\end{array}$ \\
\hline 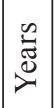 & ஓे̀े & 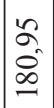 & $\begin{array}{l}\hat{n} \\
\hat{n}\end{array}$ & $\begin{array}{l}\bar{N} \\
\stackrel{2}{\Omega}\end{array}$ & $\begin{array}{l}\infty \\
\infty \\
8 \\
0\end{array}$ & $\frac{\partial}{m}$ & $\begin{array}{l}\bar{\infty} \\
\stackrel{-}{-}\end{array}$ & 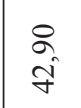 & ô \\
\hline & 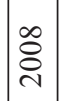 & $\mid \begin{array}{l}2 \\
\hat{0} \\
\underline{0}\end{array}$ & $\begin{array}{l}\mathscr{\infty} \\
\infty \\
\infty\end{array}$ & $\begin{array}{l}\vec{\infty} \\
\underline{0} \\
\varrho\end{array}$ & 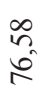 & $\begin{array}{l}\vec{b} \\
\infty \\
\infty \\
\infty\end{array}$ & $\begin{array}{l}\text { q+a } \\
\tilde{j}\end{array}$ & 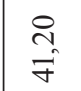 & $\stackrel{\vartheta}{2}$ \\
\hline & 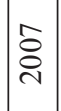 & 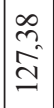 & $\overrightarrow{\tilde{n}}$ & $\begin{array}{l}\text { ô } \\
\text { - } \\
\end{array}$ & $\frac{n}{6}$ & $\begin{array}{l} \pm \\
\dot{m} \\
m\end{array}$ & $\begin{array}{l}\widetilde{0} \\
\infty \\
\infty\end{array}$ & $\stackrel{\vec{\sigma}}{\vec{i}}$ & $\begin{array}{l}\bar{b} \\
\stackrel{\infty}{0}\end{array}$ \\
\hline & 号 & $\begin{array}{l}\infty \\
\infty \\
\tilde{N} \\
\end{array}$ & 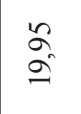 & 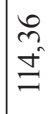 & $\begin{array}{l}\text { वे } \\
\text { oे }\end{array}$ & $\begin{array}{l}3 \\
6 \\
0 \\
\sim\end{array}$ & $\begin{array}{l}\infty \\
\infty \\
\cong\end{array}$ & $\begin{array}{l}\stackrel{q}{+} \\
\stackrel{\infty}{=}\end{array}$ & $\begin{array}{l}\stackrel{0}{2} \\
\stackrel{2}{2}\end{array}$ \\
\hline & 离 & $\begin{array}{l}\hat{\infty} \\
0 \\
0 \\
0\end{array}$ & $\begin{array}{l}\vec{F} \\
\infty \\
\infty\end{array}$ & $\begin{array}{l}\stackrel{尺}{0} \\
ٍ\end{array}$ & $\begin{array}{l}\hat{n} \\
\tilde{f}\end{array}$ & $\begin{array}{l}\tilde{n} \\
\tilde{\sim}\end{array}$ & $\begin{array}{l}\text { a } \\
\text { i }\end{array}$ & $\begin{array}{l}\vec{n} \\
\varrho_{0}\end{array}$ & $\stackrel{\overbrace{}}{\cong}$ \\
\hline & $\stackrel{8}{\circ}$ & $\begin{array}{l}\delta \\
\delta \\
i \\
i\end{array}$ & $\begin{array}{l}\stackrel{\infty}{\circ} \\
\stackrel{0}{0}\end{array}$ & $\begin{array}{l}\hat{N} \\
\hat{\imath}\end{array}$ & $\begin{array}{l}\text { के } \\
\text { âd }\end{array}$ & $\begin{array}{l}\stackrel{+}{\sim} \\
\infty \\
\infty\end{array}$ & $\begin{array}{l}2 \\
\infty\end{array}$ & mे & \&. \\
\hline & $\stackrel{\infty}{\circ}$ & $\begin{array}{l}\hat{0} \\
\text { +े }\end{array}$ & $\begin{array}{l}\stackrel{\text { }}{\infty} \\
\infty\end{array}$ & $\begin{array}{l}\bar{\sigma} \\
\delta\end{array}$ & $\begin{array}{l}\overrightarrow{\hat{\sigma}} \\
\text { î }\end{array}$ & $\begin{array}{l}8 \\
\therefore \\
1\end{array}$ & $\begin{array}{l}8 \\
8 \\
+\end{array}$ & $\begin{array}{l}\infty \\
\text { in }\end{array}$ & $\stackrel{\infty}{\sim}$ \\
\hline & 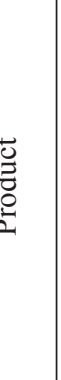 & $\begin{array}{l}4 \\
\ddot{\Xi} \\
\ddot{\infty}\end{array}$ & 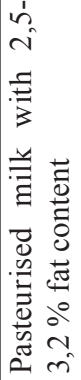 & 离 & 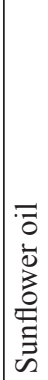 & 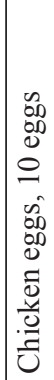 & 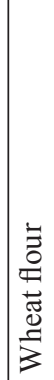 & 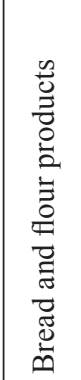 & 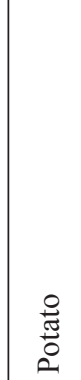 \\
\hline
\end{tabular}




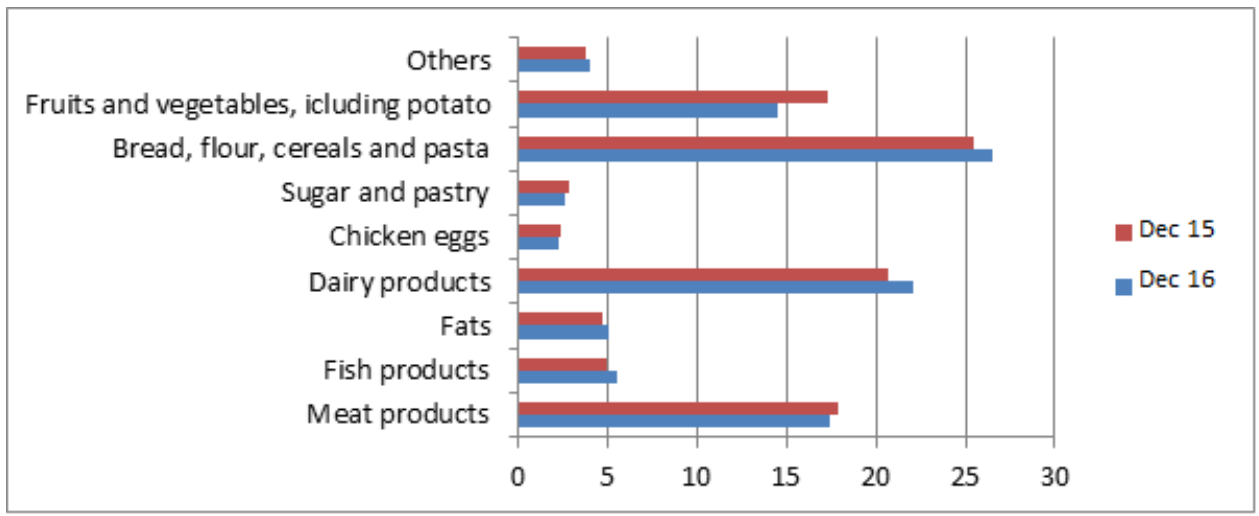

Fig. 2. The structure of the value of a fixed set of food products in the Krasnoyarsk Territory

\section{Methods}

For many years, the Department of Trade and Marketing of Siberian Federal University has been conducting research into the problems of the functioning of the food market, including new patterns of behavior of market actors, principles and logic of networked business organization (Kuimov et al., 2016; 2015). Based on the study of the activities of commodity producers in the region, the article draws conclusions about the structure of the food production market and its dynamics. In order to assess the current situation, for several years a study of the "observation" format has been conducted, which allows us to generalize the parameters of the supply of food products in the region's retail sales market, including assortment, prices, and methods of sales.

\section{Discussion}

The market of food products of the Krasnoyarsk Territory and the city of Krasnoyarsk is developing according to its own scenario, different from the European part of the country. According to expert estimates, the dominant position that is about $45 \%$ of the market is occupied by local trading companies. Chain retailing in food products in Krasnoyarsk is represented by regional retail chains of different scale. The largest players are retail chains "Komandor" and "Krasnyi Iar". These chains are also active in the development of the regions of the Krasnoyarsk Territory.

Federal and foreign players are increasing their share of presence in the Krasnoyarsk Territory market, but they are doing this gradually. Strong federal and international chains, which are well represented in the regional center, are not yet rushing to develop the territory of the region (Table 7). According to the players' estimates, federal and foreign retailers account for about $40-45 \%$ of the structured market of the Krasnoyarsk food retailing (in 2011 experts estimated this share as $15-20 \%$ ). Such a distribution of forces is not typical for the European part of Russia, where "federal" and foreign companies dominate.

Changes in the political and economic situation in the world community have determined some trends in the functioning of the food markets of Russian regions. On August 6, 2014, Presidential Decree No. 560 "On the application of certain special economic measures to ensure the security of the Russian Federation" came into effect, which limited the importation of certain agricultural products, raw materials and foodstuffs to Russia. The ban touched on goods produced in countries that imposed sanctions against Russian citizens and companies. In particular, those are all the countries of the 
Table 7. Retail chains operating in the Krasnoyarsk Territory

\begin{tabular}{|c|c|c|c|c|}
\hline Chain/company title & Status & Format & $\begin{array}{l}\text { Number of retail } \\
\text { facilities, ones }\end{array}$ & $\begin{array}{l}\text { Total area of retail } \\
\text { facilities, sq. m. }\end{array}$ \\
\hline 1. "METRO" & International & Cash and carry & 2 & 16315 \\
\hline 2. "OK" & Federal & Hypermarket & 3 & 17000 \\
\hline 3. "Lenta" & Federal & Hypermarket & 3 & 17250 \\
\hline 4. "Magnit" & Federal & Hypermarket & 2 & No data available \\
\hline 5. "FixPrice" & Federal & Discount store & 13 & No data available \\
\hline $\begin{array}{l}\text { 6. "Komandor" Group of } \\
\text { Companies }\end{array}$ & Regional & $\begin{array}{c}\text { Hypermarket; } \\
\text { Supermarket; } \\
\text { Neighbourhood store; } \\
\text { Discount store }\end{array}$ & 135 & 479576 \\
\hline 7. "Krasnyi Iar" & Regional & $\begin{array}{l}\text { Grocery store; } \\
\text { Discount store }\end{array}$ & 83 & 39912 \\
\hline 8. "Chistye Luga" & Regional & Neighbourhood store & 45 & 1900 \\
\hline 9. "Krasnoiarskii khleb" & Regional & Neighbourhood store & 39 & н/д \\
\hline 10. "Big C" & Regional & Grocery store & 13 & 16000 \\
\hline 11. "Svetofor" & Regional & Discount store & 20 & 24000 \\
\hline 12. ROSA & Regional & Supermarket & 15 & 18700 \\
\hline 13. "Miasnichii” Trading House & Regional & Neighbourhood store & 7 & 850 \\
\hline
\end{tabular}

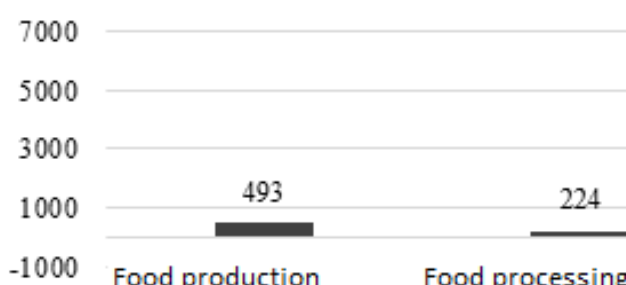

Fig. 3. Number of enterprises by type of activity, units

European Union, the USA, Canada, Australia and Norway.

The Russian food embargo was most quickly responded to by the trade sector, since banned goods are mainly imported goods entering the wholesale chain and further to the retail counters. The current market situation immediately dictated the conditions of activity for Russian producers, producers from other countries, both forming limits and providing opportunities.

The modern food market of the region represents a complex combination of the actions of regional food producers, its processors, the efforts of economic entities of neighboring regions and food importers to enter and consolidate in this market, as well as trade that ensures the sale of these goods to the end consumer.

Studies have shown that the number of intermediaries (wholesale and retail traders) is greater than the number of producers and processors in the structure of the food market in the region: one manufacturer and processor account for almost 14 trading enterprises (5 wholesale and 9 retail ones).

It was the sphere of trade that assumed responsibility for the so-called front of actions to 
change the structure of the food supply market, which determined the change in the parameters of functioning for all its participants.

If we miss the price aspects, then there are no special changes for the consumer in the retail sales of food products as such. However, business entities have carried out and are still doing colossal work to replace the relevant assortment items and the list of supplier countries that fell under the ban of products by analogues from other countries and similar Russian goods. The most "affected" category is elite cheeses. But even here solutions were found long ago: this is Switzerland, which was not affected by the sanctions with its own cheese, these are producers from Argentina, Chile; cheese is actively supplied by Belarus and Kazakhstan. Retail chains actively switched to work with Far Eastern seafood producers. European fruits and vegetables are replaced by fruits from Middle and Southeast Asia, the famous Polish apples - by apples from Serbia.

The results of research on the situation in the food sales market show that retail trade enterprises in the city of Krasnoyarsk offer the consumer a wide range of food products, most of them in domestic production (Table

Table 8. Assortment of basic food products in federal retail chains of the city of Krasnoyarsk, items/including imported ones (February 2017)

\begin{tabular}{|c|c|c|c|c|}
\hline Products & Lenta & Svetofor & $\mathrm{OK}$ & Metro \\
\hline 1 & 2 & 3 & 4 & 5 \\
\hline 1. Milk & 6 & 1 & 43 & $14 / 2$ \\
\hline 2. Sour cream & $6 / 1$ & 3 & 15 & 8 \\
\hline 3. Farmer cheese & 3 & - & 11 & 12 \\
\hline 4. Eggs & 2 & 1 & 6 & 6 \\
\hline 5. Beef & 7 & - & 14 & 15 \\
\hline 6. Pork & 4 & 1 & 13 & 20 \\
\hline 7. Chicken & 4 & 1 & 20 & 5 \\
\hline 8. Cooked sausage & 15 & 3 & 23 & 16 \\
\hline 9. Cooked smoked sausage & $15 / 1$ & 1 & 32 & 14 \\
\hline 10. Sausages & 10 & 4 & 13 & 18 \\
\hline 11. Wheat bread & 7 & 1 & 11 & - \\
\hline 12. Rye bread & 3 & - & 8 & - \\
\hline 13. Buckwheat & 5 & 1 & 19 & 9 \\
\hline 14. Rice & 4 & 1 & 20 & 17 \\
\hline 15. Millet & 6 & - & 17 & 12 \\
\hline 16. Pasta - elbows & $15 / 7$ & 1 & 34 & $6 / 2$ \\
\hline 17. Spaghetti & $8 / 2$ & 1 & 23 & $12 / 2$ \\
\hline 18. Butter & 18 & - & 21 & 23 \\
\hline 19. Cheese & $25 / 5$ & 5 & 15 & $50 / 3$ \\
\hline 20. Sunflower oil & 9 & 1 & 18 & 15 \\
\hline 21. Fresh-frozen fish & 19 & - & 25 & 76 \\
\hline 22. Sugar & 2 & 1 & 6 & 9 \\
\hline 23. Straight white wheat flour & 4 & 1 & 9 & $5 / 7$ \\
\hline 24. Meat pelmeni & $23 / 1$ & 2 & 13 & 26 \\
\hline
\end{tabular}


8). The widest intraspecific assortment for choosing is offered to consumers by the retail chains "Metro" and "OK". Such retail chains as "Svetofor" form their competitive advantages due to the price factor and the reduction of logistics costs, the costs of maintaining a wide range.

Regional trade networks also form a wide choice of food products for the consumer (Table 9). Such goods as milk are offered in the assortment of 7 to 32 items, sour cream is presented by 3-14 types, the consumer has an average choice of 15 types of boiled sausage.
Imported products are presented only in several categories of basic food products that have been evaluated. This is pasta, cheese, butter. The import is present in a certain share; the assortment is formed mainly by Russian goods. The main suppliers of the main imported food products represented in Krasnoyarsk retail trade are Finland, Belarus, Serbia, Germany, Italy, Spain, Argentina, Norway, Armenia, etc. (Table 10).

The growth of loyalty to local producers, formed in recent years, contributes to the increase in the share of regional products in the product

Table 9. Assortment of basic food products in regional retail chains of the city of Krasnoyarsk, items/including imported ones (February 2017)

\begin{tabular}{|c|c|c|c|c|c|c|c|c|}
\hline Products/retail chains & Alleia & Komandor & Khoroshii & $\begin{array}{l}\text { Krasnyi } \\
\text { iar }\end{array}$ & Baton & Big C & Rosa & $\begin{array}{c}\text { Chistye } \\
\text { Luga }\end{array}$ \\
\hline 1. Milk & 32 & 29 & 5 & 6 & 3 & 6 & 10 & 4 \\
\hline 2. Sour cream & 14 & 9 & 3 & $5 / 1$ & 6 & 5 & $7 / 1$ & 3 \\
\hline 3. Farmer cheese & 4 & 1 & 1 & 7 & - & 4 & $7 / 1$ & - \\
\hline 4. Eggs & 6 & 3 & 4 & 4 & 2 & 5 & 8 & - \\
\hline 5. Beef & 1 & 1 & - & 5 & - & 9 & 3 & - \\
\hline 6. Pork & 6 & 2 & 1 & 4 & - & 5 & 2 & - \\
\hline 7. Chicken & 1 & 2 & 1 & 4 & 1 & & 6 & - \\
\hline 8. Boiled sausage & 12 & 5 & 9 & 17 & 9 & 4 & 20 & 10 \\
\hline 9. Cooked smoked sausage & 16 & 10 & 7 & $19 / 1$ & 1 & 9 & 23 & 1 \\
\hline 10. Sausages & 6 & 7 & 4 & 18 & 2 & 5 & 23 & 5 \\
\hline 11. Wheat bread & 6 & 5 & 1 & 4 & 1 & 7 & 8 & 1 \\
\hline 12. Rye bread & 4 & - & 1 & 5 & 2 & - & 6 & 1 \\
\hline 13. Buckwheat & 9 & 6 & 3 & 5 & 2 & 6 & 7 & 1 \\
\hline 14. Rice & 15 & 12 & 5 & 6 & 1 & 5 & 28 & - \\
\hline 15. Millet & 4 & 4 & 1 & 3 & 1 & 5 & 5 & 1 \\
\hline 16. Pasta - elbows & 6 & $9 / 1$ & 6 & $34 / 12$ & 2 & 4 & $25 / 4$ & - \\
\hline 17. Spaghetti & $6 / 1$ & $13 / 1$ & 2 & $16 / 3$ & 1 & 6 & $14 / 4$ & - \\
\hline 18. Butter & 10 & 11 & 5 & 11 & 4 & 8 & $27 / 1$ & 4 \\
\hline 19. Cheese & $34 / 3$ & $27 / 2$ & 6 & $30 / 9$ & 7 & 7 & 29 & 10 \\
\hline 20. Sunflower oil & 14 & 8 & 5 & 17 & 2 & 5 & 13 & 1 \\
\hline 21. Fresh-frozen fish & $21 / 1$ & 11 & 5 & $28 / 2$ & 5 & 8 & 15 & - \\
\hline 22. Sugar & 7 & 3 & 3 & 6 & 2 & 4 & 9 & 1 \\
\hline 23. Straight white wheat flour & 4 & 3 & 1 & 3 & 1 & 3 & 12 & 1 \\
\hline 24. Meat pelemeni & 18 & 9 & 6 & 29 & 5 & 8 & 19 & 2 \\
\hline
\end{tabular}


Table 10. Countries-suppliers of food products to the market of the Krasnoyarsk Territory

\begin{tabular}{|l|l|}
\hline \multicolumn{1}{|c|}{ Product groups } & \multicolumn{1}{c|}{ Countries } \\
\hline Milk & Finland, Belarus \\
\hline Sour cream & Belarus \\
\hline Farmer cheese & Belarus \\
\hline Cooked smoked sausage & Serbia \\
\hline Pasta - elbows & Germany, Italy, Spain \\
\hline Spaghetti & Germany, Italy, Spain, France \\
\hline Butter & Germany \\
\hline Cheese & Italy, Switzerland, Holland, Belarus, Armenia, Argentina \\
\hline Straight white wheat flour & Finlnd \\
\hline Meat pelmeni & Lithuania \\
\hline Fresh-frozen fish & Norway \\
\hline
\end{tabular}

range of retail chains. The share of regional products in the range of regional retail chains grew from $16-18 \%$ in 2014 to $35-40 \%$ in 2016.

The current situation of the commodity supply in the markets of food products is characterized by a very wide range and the constantly updated list of products at manufacturing enterprises.

Each retail enterprise independently selects manufacturers and suppliers of products in order to form an optimal assortment policy proceeding from their interests and possibilities. In this case, the product itself, the terms of supply (price, terms, payment time) and logistical and marketing support are of importance. It is retail trade that should create opportunities for the development of the market for regional producers. What is the current situation?

The structure of the product assortment of regional production in retail chains is represented by:

- goods produced in the region under local and federal brands;

- private label of the chain (if the participants in the process are regional producers, which is often not the case);

- goods of own production, sold in the stores of the chain.
In the category of products produced on the territory of the region, in addition to the products of local producers, a number of federal and international holdings whose production capacities are located on the territory of the region are represented by such companies as Dymov, Coca-Cola, Danone.

The presence of such production on the one hand indicates favorable conditions for the organization of production in the region, and on the other hand, speaks of the inability of local enterprises to compete with federal and international companies. Before becoming a holding structure, many enterprises operated independently, for example, Milko Krasnoyarsk Milk Plant currently owned by Danone Russia JSC.

In the structure of the range of retail chains, such products of local producers as confectionery products and dairy products are widely represented. They are successfully realized along with federal and foreign trademarks. Some local products take a leading position in the market and are successfully realized not only in the Krasnoyarsk Territory, but also in the territory of other regions. Thus, the products of Krasnoyarsk Mayonnaise Plant LLC are the leader in the market of mayonnaises. 
Food retail has managed to adapt quickly to new post-sanction conditions and form a highquality offer on the market. However, it should be recognized that regional food manufacturers are experiencing strong competition from products of other Russian regions. For example, according to experts, about $80 \%$ of dairy products on the shelves of retail chains are imported (Stolitsa 24).

The main problems in the development of marketing of regional products are:

Small volumes of production, the need to organize frequent supplies to the retail chain, high logistics costs (30-40\%). Other barriers to enter the retail chains' market;

Problems of seasonality and shelf life. Working with natural raw materials assumes a limited shelf life of finished products and raw materials. Climatic conditions determine, in turn, the complex formation and maintenance of raw materials;

Weak marketing support for the product. Small marketing budgets.

An assessment of the current situation suggests that many trading retail chains are narrowing their assortment list by reducing the assortment groups and types within them. This is largely determined by a decrease in the income of the population. According to the estimates of the Association of Retailers, purchasing power is falling in all categories of goods, the structure of consumption is changing, and demand is shifting towards the consumer's most needed and cheaper goods. The statistics also confirm the decline in the purchasing power of the Russian Federation's incomes, starting from 2013 (Table 11).

Table 11. Purchasing power of average monetary income of the population of the Russian Federation (kg)

\begin{tabular}{|l|c|c|c|c|c|}
\hline & 2012 & 2013 & 2014 & 2015 & 2016 \\
\hline \multicolumn{1}{|c|}{1} & 2 & 3 & 4 & 5 & 6 \\
\hline Beef & 95,2 & 105,3 & 108,8 & 98,0 & 92,9 \\
\hline Chicken & 214,3 & 236,5 & 231,6 & 222,0 & 221,4 \\
\hline Fish & 229,4 & 250,5 & 239,4 & 192,3 & 171,9 \\
\hline Milk & 602,2 & 630,5 & 570,3 & 560,5 & 514,6 \\
\hline Butter & 91,4 & 93,6 & 82,1 & 78,0 & 70,8 \\
\hline Black tea & 40,3 & 42,1 & 41,0 & 33,4 & 28,9 \\
\hline
\end{tabular}

Table 12. Private label in the range of retail chains functioning in the Krasnoyarsk Territory

\begin{tabular}{|l|c|c|c|c|}
\hline \multirow{2}{*}{ Chain/company title } & \multicolumn{3}{|c|}{ Number of denominations of Private label/Number of items in assortment } \\
\cline { 2 - 5 } & 2010 & 2014 & 2015 & 2016 \\
\hline 1. "METRO" & $41000 / 3526$ & $5858 / 43584$ & $5500 / 50000$ & $9048 / 52000$ \\
\hline 2. "OK" & - & $5120 / 64000$ & 768064000 & $9600 / 64000$ \\
\hline 3. "Lenta" & - & $2691 / 23000$ & $3380 / 26000$ & $3900 / 30000$ \\
\hline 4. "Magnit" & - & - & $3472 / 31000$ & $3990 / 35000$ \\
\hline 5. "Komandor" & No data available & $352 / 31000$ & $592 / 29600$ & $462 / 30000$ \\
\hline 6. "Krasnyi Iar" & No data available & $258 / 18400$ & $300 / 20000$ & $336 / 21000$ \\
\hline 7. "Chistye Luga" & No data available & $260 / 415$ & $216 / 240$ & No data available \\
\hline
\end{tabular}


In these conditions, in order to strengthen the position of the brand of the retail chain, increase the company's profitability and expand the assortment, the private label technology is actively used. Private label is a product that is produced under the brand and on the order of a particular retail chain. Currently, goods sold under the auspices of private label are present in the assortment of most retail chains functioning in the Krasnoyarsk Territory (Table 12).

The largest number of assortment units manufactured and offered under private label is represented in retail chains of international and federal format. The reasons for the active use of the private label technology are increased competition and the need to avoid direct price comparison, reduction of real incomes of the population and search for ways to preserve buyers and, as a consequence, gain and profit. The difference in the cost of private labels with similar products of brands of manufacturers is from 15 to $30 \%$ for different product categories (Table 13-14). This is conditioned by the lack of costs for advertising, brand promotion, savings on packaging, and a reduction in logistics costs due to the lack of intermediate links between production and the store.

The given data of the food retail survey of the Krasnoyarsk Territory characterize the growth in the share of private label goods from federal

Table 13. Comparative price characteristics of private label products to a similar product in the store (for example, Krasnyi Iar)

\begin{tabular}{|c|c|c|c|}
\hline No. & Product & Manufacturer & $\begin{array}{c}\text { Price of private label in \% in relation to } \\
\text { a similar product in the store }\end{array}$ \\
\hline 1 & Condensed milk & Prostoi Vybor & $60 \%$ \\
\hline 2 & Butter & Selo Masloboevo & $72 \%$ \\
\hline 3 & Milk & Selo Masloboevo & $72 \%$ \\
\hline 4 & Buttermilk & Selo Masloboevo & $100 \%$ \\
\hline 5 & Fermented baked milk & Selo Masloboevo & $71 \%$ \\
\hline
\end{tabular}

Table 14. Share of goods under private label in retail chains' turnover

\begin{tabular}{|c|c|c|c|c|c|c|}
\hline \multirow{2}{*}{$\begin{array}{c}\text { Chain/company } \\
\text { title }\end{array}$} & \multirow{2}{*}{ Status } & \multirow{2}{*}{ Format } & \multicolumn{4}{|c|}{ Share of private label in turnover, $\%$} \\
\hline & & & 2010 & 2014 & 2015 & 2016 \\
\hline 1. "METRO” & International & cash and carry & 8,6 & 11,3 & 11 & 17,14 \\
\hline 2. "OK" & Federal & hypermarket & $\begin{array}{c}\text { No data } \\
\text { available }\end{array}$ & 8 & 2 & 5 \\
\hline 3. "Lenta" & Federal & hypermarket & - & 11,7 & 13 & 13 \\
\hline 4. "Magnit" & Federal & hypermarket & - & - & 11,2 & 11,4 \\
\hline 5. "Komandor" & Regional & $\begin{array}{c}\text { hypermarket; } \\
\text { supermarket; } \\
\text { neighbourhood store; } \\
\text { discount store }\end{array}$ & 8,9 & 5 & 2 & 1,54 \\
\hline 6. "Krasnyi Iar" & Regional & $\begin{array}{l}\text { grocery store; } \\
\text { discount store }\end{array}$ & 9 & 1,4 & 1,5 & 1,6 \\
\hline 7. "Chistye Luga" & Regional & neighbourhood store & 60 & 62,6 & 90 & 87 \\
\hline
\end{tabular}


retail chains (Magnit, Lenta and $\mathrm{OK}$ ), and the reduction of this indicator among regional retail chains ("Komandor", "Krasnyi Iar", "Chistye Luga"). The largest increase in the share of goods of the private label category is demonstrated by the international retail chain "METRO", which increased the share of goods under private label to $17.14 \%$ in the total sales volume.

The situation of the private label format development in the market of the Krasnoyarsk Territory is identical to Russian and world trends. The share of private label goods in the segment of everyday goods in Russia as a whole increases annually and reaches $5.1 \%$ in 2016 (Fig. 4).

World trends in the development of private label state that the retail chains of world leaders, such as ALDI. LIDL, have the share of private label in the range of goods that is $70-80 \%$. Thus, the share of private label in Switzerland accounted for $45 \%$, Britain, in Spain - for $41 \%$, in Germany - for $32 \%$. There is a great potential for the development of private label in Russia and the Krasnoyarsk Territory. According to RomirScanPanel of households in 2015, $96 \%$ of Russian consumers purchased goods under private labels at least once a year (Kuimov, 2015).

The partners of the chain that produce private chain products or by chain standards are both local producers and companies of another region. At the same time, the following factors influence the choice of the partner:

1. The ability to follow the specified quality standards of production.
2. The ability to provide the necessary volume and rhythm of production.

\section{Logistical costs.}

Regional retail chains are currently working to expand the range of local production and own production using local raw materials. Large retail chains can act as an effective catalyst for local production. However, in pursuit of their business goals, retail chains are currently playing a different role, creating serious competitive conditions for the products of local producers, compelled to withstand the rivalry of the mass of goods from other countries and regions of Russia, which are offered by the retailers in a wide range.

Thus, the formation of food prices is largely determined by retail chains. In the structure of the value of food commodities, expenditures on commodity circulation, taxes, and intermediary costs prevail in contrast to the cost of production of goods. With an increase in the price of food, the redistribution of the price load does not occur at the expense of reducing the intermediary part of the allowances, but at the expense of cheapening of raw materials, reducing the cost of sorting, packing and storing the goods (increasing the shelf-life means using the artificial components of the product). In the formation of prices for socially important food products, costs of retail outlets for renting premises, marketing and branding play a decisive role (Sotsial'no-ekonomicheskoe polozhenie Sibirskogo...).

Rigid conditions of competition for the products of local producers determine the cheap

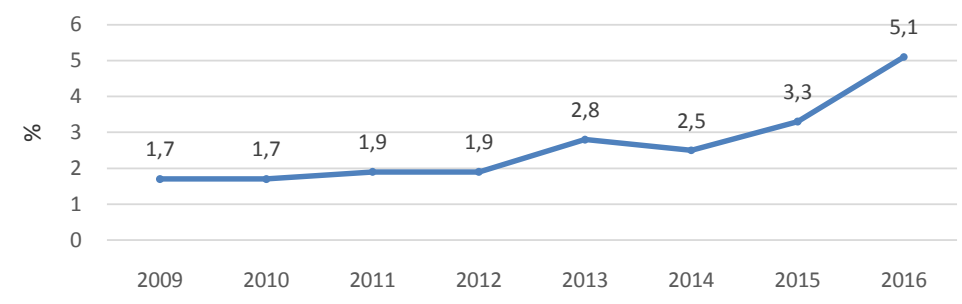

Fig. 4. Share of private label goods in the segment of everyday goods in Russia 
(often poor quality) foods presented by retailers in the region, as well as food sold under a falsified trademark. The trend of growth in demand for fast food products is actively supported by retail chains through the expansion of an assortment of dangerous and harmful to human health products, including sweet carbonated drinks, snacks, longterm storage products and unreasonably high caloric content.

The desire to offer a more affordable product to the consumer generates the demand of retail chains and the purchase of food at a reduced cost by mixing quality raw materials with lowquality ones, raw materials of a different grade, increasing the shelf life of food products (products with transgenic ingredients, using palm oil or goods of doubtful origin).

The supply of large retailers of the FMCG format with food requires the purchase of large quantities of goods. For their production manufacturing enterprises do not always use high-quality and natural raw materials because of the shortage of production capacities of the agrarian sector (dairy and meat cattle breeding, fish farming). In addition, the domestic auxiliary production of food dyes, spices, emulsifiers, color stabilizers, thickeners, etc., is poorly developed.

The results of the inspection of the Krasnoyarsk Center for Standardization, Methodology and Testing, conducted throughout 2016 and in previous years, will allow us to judge about the scale of falsification of food. Thus, for example, the inspection of the samples of butter present in the retail sale from December 14, 2016 showed that "... one third of the samples were found not to meet the quality and safety requirements ....". Experts examined 15 samples of oil with a mass fraction of fat of $72.5 \%$ purchased in the retail chains of the regional center. Products are manufactured in the cities of Minusinsk and Krasnoyarsk, in Berezovsky, Emelyanovsky, Novoselovsky, Sukhobuzimsky districts of the Krasnoyarsk Territory, as well as in other regions of the Russian Federation, namely, Moscow, Novosibirsk, Chelyabinsk regions, Khakassia and Bashkortostan. If previously $10-15 \%$ of products were withdrawn during the inspections as obviously substandard, now their number has increased to $50 \%$, and in some cases to $100 \%$.

Increased competition from local food brands of neighboring regions is another factor in the formation of the region's food market. The formation of the commodity offer by the federal retail chains "OK", "Metro", "Magnit" mainly takes place centrally at the location of the transport hub, which explains a big number of mainly dealer brands of own production of Novosibirsk, Kemerovo, St. Petersburg commodity producers in these shops. Competition for Krasnoyarsk commodity producers is strengthened by the access of retail chains from neighboring regions to the Krasnoyarsk food market, including Kemerovo retail chain "Kalina-malina", Khakassia retail chain "Mavr" and Krasnodar retail chain "Magnit".

A number of small retail chains of "neighborhood store" format satisfy the steady solvent demand for eco-friendly, fresh, highquality products of local producers in the Krasnoyarsk Territory, namely "Lavka poleznye produkty", "Moloko i miaso", "Provintsiia", "Chistye luga" and "Prem'er, butcher's shop". The widest range of products is offered only by the chain of stores "Lavka poleznye produkty", where products are predominantly dairy ("Sibirzhinka"), meat ("Tesinsky"), bakery products ("Melnik", "Divinka"), mineral waters ("Tagarskaya"), some fruit and vegetable conservation. Besides, dairy and meat products are represented by enterprises of the Minusinsk District of the Krasnoyarsk Territory that is the territory with the best ecological conditions of agricultural production. 
The barrier of small volumes of supply is often the main obstacle for cooperation of local commodity producers with large trade networks. This problem is solved by the application of practices of brand summarization of brand producers by means of implementation of integration strategies. Thus, for example, the brand "Selo rodnoe" united under itself production of several agricultural producers. Such a merger of various manufacturers allowed reducing expenses on transport logistics, and, accordingly, adjusting pricing. At the moment the brand is represented in regional retail chains, the quality control of the brand's products is conducted by the Krasnoyarsk Center for Standardization, Metrology and Testing. This is control over the production of goods at a plant and technological audit of its own production. At this stage, the brand "Selo rodnoe" is represented only by dairy products, but in the future the brand plans to expand the assortment to meat, vegetable, etc.

\section{Conclusion/Results}

The research allowed summarizing a number of factors that shape the competitive situation of brands of local commodity producers in the food market of the Krasnoyarsk Territory.
It should be noted that the strength of these factors is largely determined by retail chains. In particular, it is:

- Formation of food prices by retail chains;

- A high percentage of falsified food sold under a counterfeit trademark;

- Increased competition from local food brands of neighboring regions;

- Underdevelopment of local food markets.

In general, the retail food market in Krasnoyarsk and the region as a whole creates conditions for the development of local food production, one of the tasks of which is harmonization of relations with major retail chains and retail in general. This implies, among other things, both the formation of retail chains operating in the region and the participation in the formation of through (production-processinglogistics centers-retail) differentiated productiondistributing lines on the basis of various integration forms of business on the production and sale of regional and domestic manufacturers' products (associations, strategic alliances, tradepurchasing cooperatives, unions, organization of private label production).

\section{References}

Agropromyshlennyi kompleks Sibirskogo federal'nogo okruga. 2010-2014 [Agroindustrial complex of the Siberian Federal District. 2010-2014]. Barnaul, Altaikraistat, 156 p.

Federal'naia sluzhba gosudarstvennoi statistiki po novosibirskoi oblasti: ofitsial'nyi sait [Federal state statistics service in Novosibirsk region: the official website]. Available at: http://www.novosibstat.gks.ru/

Kuimov, V.V., Suslova, Y.Y., Shcherbenko, E.V., Tolstoy, D.A., Kuimov, A.O. (2016). Regional'nye tekhnologicheskie platformy kak instrument innovatsionnogo razvitiia territorii: monografiia [Regional technology platforms as a tool for innovative development of the territory: monograph]. Moscow, INFRA-M, 343 p.

Kuimov, V.V., Suslova, Y.Y., Shcherbenko, E.V, Pankova, L.V. (2015). Marketingovye tekhnologii $v$ razvitii rynkov prodovolstvennykh tovarov regionov Sibiri [Marketing techniques in the development of food markets of Siberian regions]. Krasnoyarsk, SFU, 268 p.

Pokupatel'naia sposobnost' rossiian [The purchasing power of Russians]. Available at: https:// news2.ru/story/485750/ (accessed 15.11.2016). 
Regiony Rossii. Sotsial'no-ekonomicheskie pokazateli [The Regions of Russia. Socio-economic indicators] (2006). Moscow, Rosstat, 1326 p.

Rossiiskii statisticheskii ezhegodnik 2016 [Russian statistical yearbook 2016]. Moscow, Rosstat, $725 \mathrm{p}$.

Shcherbenko, E.V. (2011). Marketing v formirovanii sistemy prodovol'stvennogo obespecheniia regiona [Marketing in shaping the food systems of the region]. Novosibirsk, Nauka, $456 \mathrm{p}$.

Shcherbenko, E.V., Firsenko, S.S. (2009). Formirovanie sistemy prodovol'stvennoi bezopasnosti regionov: monografia [The formation of the system of food security in the region]. Novosibirsk, Nauka, 400 p.

Sotsial'no-ehkonomicheskii monitoring sub"ektov Sibirskogo federal'nogo okruga: statisticheskii biulleten' 2017 [Socio-economic monitoring of the regions of the Siberian Federal istrict: statistical bulletin 2017]. Novosibirsk, Territorial body of Federal state statistics service in Novosibirsk region, $151 \mathrm{p}$.

Sotsial'no-ekonomicheskoe polozhenie Rossii v 2016 godu [The socio-economic situation in Russia in 2016]. Moscow, Rosstat, 371 p.

Sotsial'no-ekonomicheskoe polozhenie Sibirskogo federal'nogo okruga v 2016 godu [The socioeconomic situation of the Siberian Federal District in 2016]. Moscow, Rosstat, 83 p.

Stolitsa 24 [The Capital 24]. Available at: http://stolitca24.ru/news/v-krasnoyarskom-krae-vproshlom-godu-oborot-roznichnoy-torgovli-torgovykh-setey-sostavil - 104 -mlrd-ru/

\title{
Региональная торговля как фактор развития продовольственного рынка территории
}

\author{
Е.В. Щербенко, В.В. Куимов \\ Сибирский федеральный университет \\ Россия, 660041, Красноярск, пр. Свободный, 79
}

Приведен анализ состояния сферы торговли продовольственными товарами России. Дана оценка розничной торговли продовольственными товарами Красноярского края. Раскрыты тенденции развития сетевой торговли формата FMCG на региональном рынке. Проведена оиенка структуры стоимости минимального набора продовольственных товаров. Исследовано влияние политики санкиий на формирование рынка розничных продаж продуктов питания. Показана роль торговли в проиессе адаптаиии субъектов продовольственного рынка к условиям санкиий. Приведены данные динамики ассортимента и цен предприятий сетевой торговли на продукты питания. Показаны результаты исследования новых технологий взаимодействия производителей с торговыми сетями, в том числе технологии "Собственной торговой марки». Обобщается роль сетевой торговли в формировании конкурентных условий рынка продовольственных товаров.

Ключевые слова: продовольственный ритейл, розничная торговля, ассортимент продовольственных товаров, цены на продовольственные товары, собственная торговая марка.

Научная специильность: 08.00.00 - экономические науки. 